\title{
Chapter 9 \\ Strengths-Based and Mutual Aid \\ Approaches in Social Work \\ and Psychodrama
}

\begin{abstract}
Social work and psychodrama are both inherently strengths-based approaches with person-centered philosophies that affirm the inherent goodness of individuals. The chapter outlines social work's strengths-based perspective while connecting it to mutual aid, positive psychology, humanistic psychology, and Morenean philosophy. Social group work's emphasis on mutual aid and group-as-a-whole processes is outlined with similarities to the theory and practice of psychodrama. The importance of a strengths-based approach in trauma work is affirmed and depicted through resilience theory and post-traumatic growth. Modern adaptations of classical psychodrama which emphasize strengths work are depicted, including positive psychodrama, the Therapeutic Spiral Model, and Souldrama.
\end{abstract}

Keywords Strengths-based social work $\cdot$ Mutual aid $\cdot$ Strengths-based approach • Positive psychology $\cdot$ Strengths perspective

\subsection{Strengths-Based Social Work Practice}

The social work field has incorporated a strengths-based approach as a core aspect of its identity. The social work profession and strengths-based approach appear to have a harmonious fit considering the core values of treating everyone with dignity and worth, emphasizing relationships, and steadfastly holding hope for personal and societal change (Witkin, 2017). Instead of solely focusing on pathology, suffering, trauma, injustice, and problems, social workers uphold the belief that each individual has unique strengths and should be treated with dignity and respect. "One thing is certain ... Once a client is engaged in building up the strengths within and without, a desire to do more and to be more absorbed in daily life and drawn by future possibilities breaks out" (Saleebey, 2012, p. 111).

The emphasis on strengths is nothing new to society; history has a wealth of examples of spiritual leaders, gurus, archetypes, gods, doctors, advocates, politicians, philosophers, and writers that "sought to find the best in human capacity and desire, both individually and collectively" (Rapp, Saleebey, \& Sullivan, 2006, p. 80). The flavor of the strengths-based perspective was present from the start of the social work profession, especially in the settlement movement, the emergence of social group

S. Giacomucci, Social Work, Sociometry, and Psychodrama, Psychodrama in Counselling, 
work, and macro-social work's emphasis on democratic ideals and empowerment within society.

The application of a strengths-based approach finds itself useful in multiple facets of social work including strengths-based casework (Rapp \& Chaimberlain, 1985), strengths-based assessment (Epstein \& Sharma, 1998), the use of clients strengths in clinical social work and psychotherapy (Cohen, 1999; Rapp et al., 2006; Rashid, 2015; Saleebey, 1996; Smith, 2006), a relational emphasis of social worker and client's strengths (Rapp, 1998; Rapp et al., 2006; Witkin, 2017), group work's use of mutual aid (Gitterman \& Shulman, 2005; Northen \& Kurland, 2001; Shulman, 2015; Steinberg, 2010), community work focused on strengths or assets (Kretzmann \& McKnight, 1993; Saleebey, 1996), supervision (Alschuler, Silver, \& McArdle, 2015; Cohen, 1999; Wade \& Jones, 2014), education (Probst, 2010), and an overall paradigm shift from pathology-oriented perspectives to a health-oriented philosophy (Kim \& Bolton, 2013; Rapp, Saleebey, \& Sullivan, 2006; Saleebey, 2012).

Dennis Saleebey, in The Strengths Perspective in Social Work Practice (2012), outlines six core principles underlying the strengths-based perspective:

1. Every Individual, Group, Family, and Community Has Strengths. This foundational belief assumes that the client always has strengths and positive resources that can be used to help with the presenting problem. Regardless of the presenting problems, there are also presenting strengths that exist within the client and the environment. The strengths-based perspective allows us to see the whole picture when it comes to working with individuals, groups, families, and communities.

2. Trauma and Abuse, Illness and Struggle May Be Injurious, but They May also Be Sources of Challenge and Opportunity. This principle challenges the viewpoint that trauma and injury only create victims. Instead, the possibility of growth and new opportunities after trauma or hardship is acknowledged. This principle will be discussed at length in Sect. 9.2.2 on post-traumatic growth. Instead of strengthening a narrative of victimization after trauma, newfound strengths, post-traumatic growth, and "survivor's pride" are celebrated (Wolins, 1993).

3. Assume That You Do Not Know the Upper Limits of the Capacity to Grow and Change and Take Individual, Group, and Community Aspirations Seriously. This principle asserts that strengths-based social workers maintain high expectations and hope for clients regardless of their history or diagnosis. When a social worker perceives that growth is not possible or restricted due to deficits or diagnoses, it has a limiting impact on the client (van Breda, 2018). The strengthsbased worker takes clients visions and dreams seriously while believing in the capacity for self-healing for all clients, groups, families, and communities.

4. We Best Serve Clients by Collaborating with Them. Rather than operating as the expert and recreating an imbalance of power dynamics within the therapeutic relationship, strengths-based workers approach clients as collaborators. This principle challenges us to work with clients rather than to treat their disorder or work on them. 
5. Every Environment is Full of Resources. Regardless of place or environment, the strengths-based social worker recognizes that strengths, ideas, and possibilities exist within the environment. Even when a community is plagued with poverty, violence, and collective trauma, there are still strengths, wisdom, and important resources within the community that can be tapped for transformation.

6. Caring, Caretaking, and Context. This principle emphasizes the centrality of caring relationships in the human experience and the praxis of social work. Social caretaking is recognized as core to both the social work profession and the strengths-based perspective. The therapeutic relationship itself is a strength (Witkins, 2017), and the relationships within the client's life are celebrated as strengths.

These six principles outline the basis of the strengths-based approach, which Saleebey acknowledges is fluid and subject to changing as the strengths-based approach continues to evolve.

Working from a strengths-based approach does not mean that one avoids addressing social or psychological issues. Problems are addressed, but they are addressed from the starting point of strengths. Strengths-based social workers would argue that neglecting to acknowledge clients' problems is just as faulty as neglecting to acknowledge their strengths (Saleebey, 2012). The strengths-based approach attempts to restore "balance to the understanding of the human condition-as social workers we recognize and respect the strengths and capacities of people as well as their afflictions and agonies" (Saleebey, 2012, p. 279).

\subsubsection{Positive Psychology and Strengths-Based Social Work}

While the strengths-based social work approach emerged about a decade earlier (Weick, Rapp, Sullivan, \& Kisthardt, 1989; Saleebey, 1996) than positive psychology (Seligman, 1998), early evidence of this way of thinking in the helping professions can be traced back to William James and Abraham Maslow (Froh, 2004; Maslow, 1954). Many social workers experience positive psychology as the new face of the strengths-based approach (Witkin, 2017). The movement of positive psychology appears to have professionalized in a way that strengths-based social work hasn't, which has led to a large body of research, a graduate degree in positive psychology, and a surge of positive psychology awareness in the larger culture. Witkins (2017) critiques positive psychology for its adherence to individualism, neoliberalism, neglect of cultural subjectivity, and the lack of recognition positive psychologists give to the strengths-based social work approach which preceded it. He suggests that the strengths-based approach, like the social work field as a whole, offers positive psychologists a more relationally grounded, context-aware, and antioppression framework rooted in narratives of disenfranchised, marginalized, and colonized communities. While positive psychology aims for objectivity and universalism to complement its research-driven agenda, the strengths-based social work 
approach "does not claim nor seek to claim a universal template of virtues to which all should aspire, but that simply re-directs people to identify and utilize whatever resources and assets make sense within their social and cultural contexts" (Witkins, 2017, p. 122).

Saleebey (2012) differentiates the social work strengths-based approach from positive psychology in that the strengths-based approach: (1) recognizes that almost anything can be a strength or asset, depending on context; (2) strengths and resources exist within all relationships, groups, communities, and environments; (3) practice with clients involves helping them utilize both their internal resources/strengths and their external/environmental resources to enhance their lived experience.

\subsection{Strengths-Based Approach with Trauma}

The field of trauma therapy has evolved to integrate the use of strengths-based approaches at its core. These approaches are evidenced in the first phase of nearly every clinical map for trauma therapy which focus on strengths, safety, connection, skills building, and containment (Chesner, 2020; Courtois \& Ford, 2016; Herman, 1997; Hudgins \& Toscani, 2013; Najavits, 2002; Shapiro, 2018). The emphasis on clients' strengths in the post-traumatic context provides an avenue for (re)establishing safety on multiple layers including inner safety for the client, safety within the therapeutic relationship, and safety in the environment. Strengths are the building blocks to cultivating safety. Trauma is, at its root, a violation of safety or perceived safety. Najavitis (2002) states that "just as violations of safety are life-destroying, the means of establishing safety are life-enhancing" (pp. 5-6).

\subsubsection{Resilience}

The strengths-based approach is also present in the social worker's emphasis and celebration of clients' resilience. This emphasis on resilience has increased within the social work field in the past few decades (Gitterman \& Knight, 2016; van Breda, 2018). Norman even suggests that "resiliency enhancement is probably the most reasonable way that social worker can put the strengths perspective into practice" (2000, p. 3). Resilience is defined as the ability to bounce back from hardship or adversity, to survive, and to adapt. Resilience is strikingly similar to Moreno's definition of spontaneity in terms of the act of adaptive response (Cossa, 2020). Resiliency is at the intersection of adversity and strengths (Norman, 2000). Three types of resilience are presented by Fraser and colleagues (2004): recovery after trauma, overcoming adversity, and maintaining competence while under stress. Various factors are outlined in the literature related to resilience protective factors including intelligence, interpersonal skills, temperament, life outlook, self-esteem, self-efficacy, 
humor, adaptability, hardiness, and spirituality (Baruth \& Carroll, 2002; Gilligan, 2004; Gitterman \& Knight, 2016).

Canda (2012) proposes a new framing of resilience through a spiritual lens which he calls transilience. Transilience is defined as "a whole person process of moving forward, backward, upward, downward, sideways, or back-around in a life committed to well-being and well-becoming" which validates the nonlinear spiritual experience of resilience "and transcends the moment-to-moment details of living and dying” (p. 94). Social work with group experts also proposes a nonlinear conceptualization of resilience rooted in the relational framework of group participants helping each other-mutual aid (Gitterman \& Knight, 2016). Mutual aid, social group work's strengths-based core principle, will be explored in detail in the coming sections. "Group [membership] counteracts the isolating effects of [adversity] and enables survivors to connect with sources of resilience within themselves and others" (Mendelsohn, Zachary, \& Harney, 2007, p. 227). Mutual aid and group work move us from an individual-based conceptual of resilience to a relationally grounded, group-based understanding of resilience in social contexts and communities.

While resilience is often described as a response to adversity or the ability to bounce back from trauma, some are suggesting that it goes beyond bouncing back, but includes bouncing forward into new growth and thriving. Walsh suggests that "resiliency is promoted when hardship, tragedy, failure, or disappointment can also be instructive and serve as an impetus for change and growth" (2006, p. 79). This statement frames resilience as a type of growth after trauma, or what has been more recently termed post-traumatic growth.

\subsubsection{Post-Traumatic Growth}

Post-traumatic growth refers to phenomenon of frequently experienced following a trauma or adverse experience (Calhoun \& Tedeschi, 2014). While the term posttraumatic growth was initially used by Richard Tedeschi and Lawrence Calhoun in the mid-1990s, the phenomenon of transformation after trauma has existed for all of human history $(1995,1996,2014)$. Experiences of post-traumatic growth are organized into five domains (see Fig. 9.1):

1. New Possibilities in Life - trauma, by its nature, overwhelms and challenges an individual in ways that may have not been imagined previously. As a result, many survivors begin to see new possibilities in life and the opening of new doors of opportunity.

2. Increased Awareness of Personal Strengths - Surviving trauma and asking for help to cope with its aftermath requires incredible strength. Trauma survivors demonstrate extraordinary courage, resilience, trust, hope, and compassion, among other strengths. When an overwhelming event forces one to utilize all the strengths available (and often develop new ones), they become much more 

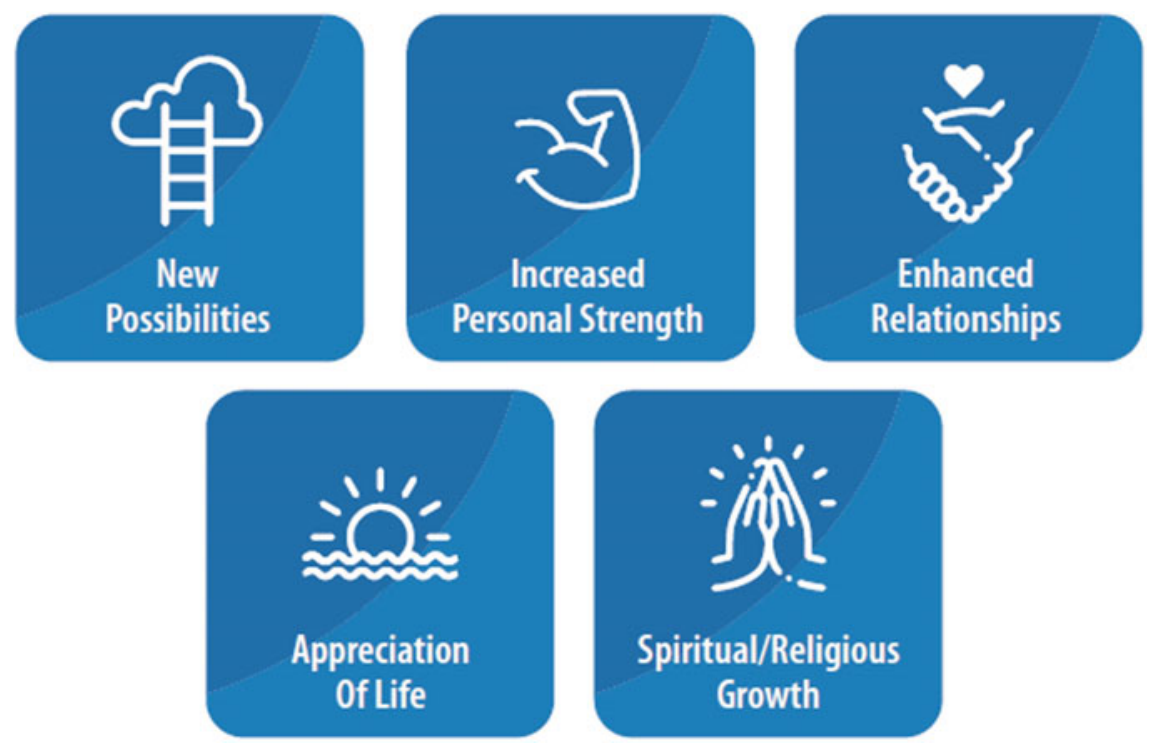

Fig. 9.1 Five domains of post-traumatic growth

aware of these strengths going forward. Many trauma survivors remark that "if I survived that trauma, I could survive anything".

3. Enhanced Relationships with Others - The process of coping with trauma requires relationships - friends, family, therapists, support groups, etc. As humans, we are neurobiologically wired to regulate our emotions through relationships. The experience of utilizing support after trauma deepens these connections and reaffirms their importance. Having experienced trauma or loss also increases one's ability to feel compassion and empathy for others in similar situations (Bauwens \& Tosone, 2010).

4. Stronger Appreciation of Life-Trauma, by its nature, threatens safety, security, and often one's life. Trauma and loss remind us how precious life is and how fragile it can be. Trauma has the ability to challenge us to see the world in a new way and to reconsider our priorities in life.

5. Spiritual or Religious Change-Trauma is so often experienced through relationships and involving other human beings, as a result, many trauma survivors turn to spirituality or religion for strength, hope, and inspiration. Trauma is an existential crisis that challenges us to make sense of it, often through spiritual, religious, or existential belief systems.

These five domains are further simplified into three conceptual categories: an enhanced sense of self, enhanced sense of relationships with others, and enhanced philosophy of life (Calhoun \& Tedeschi, 2012; Tedeschi \& Calhoun, 1996). Posttraumatic growth is the realization of a transformation that begins with a catalyst for 
change-the trauma. One might even argue that all of our personal strengths are a result of surviving and finding our way through difficulties, struggles, and hardships.

Calhoun and Tedeschi (2014) estimate that between 30-90\% of people report at least some element of growth when dealing with major difficulty life events. A later systematic review and meta-analysis of the research concluded that nearly half of participants reported moderate-to-high post-traumatic growth after a traumatic experience (Wu et al., 2019). Compared to less than a 25\% of developing PTSD after a traumatic event (Breslau, Davis, Andreski, \& Peterson, 1991; Kessler et al, 1995; Santiago et al, 2013), these statistics of post-traumatic growth are very hopeful. It is also important to state that post-traumatic growth and post-traumatic stress disorder can also be experienced simultaneously - multiple research studies have highlighted this with various populations (Alisic, Van der Schoot, van Ginkel, \& Kleber 2008; Bluvstein, Moravchick, Sheps, Schreiber, \& Bloch, 2013; Jia, Ying, Zhou, Wu, \& Lin, 2015; Parikh et al., 2015; Ssenyonga, Owens, \& Olema, 2013). At the same time, the literature shows that higher levels of post-traumatic growth are related to lower levels of PTSD symptomology (Frazier, Conlon, \& Glaser, 2001; Frazier et al., 2009; McMillen, Smith, \& Fisher, 1997; Park, Cohen, \& Murch, 1996; Ssenyonga et al., 2013). A trauma survivor is significantly more likely to report post-traumatic growth after a traumatic event then they are to develop post-traumatic stress disorder!

Multiple studies have highlighted the prevalence of vicarious post-traumatic growth for therapists and advocates working with trauma (Arnold, Calhoun, Tedeschi, \& Cann, 2005; Cohen \& Collins, 2013; Cosden, Sanford, Koch, \& Lepore, 2016; Hyatt-Burkhart, 2014; Manning, de Terte, \& Stephens, 2015). The experience of being a part of trauma therapy appears to potentially be stimulating of posttraumatic growth. Considering that this is validated for professionals, there is likely also a vicarious post-traumatic growth effect on client participants within group work. Group work positions individuals within the group to help each other cultivate post-traumatic growth through the recognition of each other strengths, the sharing of new perspectives and belief systems, and the enhancement of positive relationships.

\subsection{Mutual Aid as a Strengths-Based Group-As-A-Whole Approach}

Mutual aid is the foundation of social work with groups (Gitterman \& Shulman, 2005; Glassman \& Kates, 1990; Northern \& Kurland, 2001; Skolnik-Basulto, 2016; Steinberg, 2010). Through the mutual aid process, group members contribute to supporting and healing each other. The job of the group worker is to help facilitate the mutual aid process within groups (Kurland \& Salmon, 2006). Schwartz (1961) captures this dynamic: "This need to use each other, to create not one but many helping relationships, is a vital ingredient of the group process and constituted a common need over and above the specific task for which the group was formed" (p. 158). While the term "mutual aid" wasn't introduced to social workers until 
1961 (Schwartz), others wrote about this unique group phenomenon decades earlier (Dewey, 1916; Kropotkin, 1922; Mead, 1934; Moreno, 1947, 1955). One such mutual aid writer was Jacob L. Moreno. Moreno's experiential sociometric processes offer group workers with action-based tools to activate mutual aid within a group while working with the group-as-a-whole (Giacomucci, 2019; Skolnik, 2018).

Yalom and Leszcz (2005), in their seminal text on group psychotherapy, describe mutual aid within the framing of the therapeutic factor of altruism. They offer the poignant story of a rabbi having a conversation with God about heaven and hell in which he is shown two groups representing each. The first, symbolizing hell-a group of starving and desperate people sitting around a huge pot of delicious stew but unable to feed themselves because the only spoons available were too long-handled to reach one's own mouth. Nobody ate and everyone suffered. Heaven was represented by a second group also sitting around the same large pot of stew with the same longhandled spoons, but everyone was well nourished, healthy, and joyful because they had learned to feed each other. The altruistic nature of the second group, particularly their experience of mutually nourishing each other, is symbolic of not only heaven, but also a successful group psychotherapy session.

\subsubsection{Mutual Aid in Social Work}

William Schwartz introduced the term "mutual aid" to social workers in his 1961 article "The social worker in the group." Mutual aid refers to the process by which group members support and help each other. Steinberg (2003) posits that "catalyzing mutual aid is the heart and soul of social work practice with groups" (p. 36). A mutual aid group worker believes essentially that each group has the inherent capacity to heal itself through mutual aid. Each member of a group possesses unique strengths, insights, and experiences, in addition to a shared group intention, which can be leveraged to empower the group-as-a-whole. Shulman (2015) describes mutual aid as allowing group members to "use the group to integrate their inner and outer selves and to find more adaptive mechanisms to cope with oppression, including personal and social action" (p. 548). Various evidence sources highlight the capacity of the mutual aid process to enhance self-esteem and problem-solving skills while decreasing shame and isolation (Gitterman \& Shulman, 2005; Knight, 2006; Steinberg, 2010).

In group work, Kurland and Salmon (2006) exclaim, "the worker's role is to set in motion a process of mutual aid in the group" (p. 131). Mutual aid is a strengths-based, holistic, and anti-oppressive approach to group work, which inherently integrates the psychological, social, and experiential (Steinberg, 2010). Mutual aid group work encourages both inclusion of every group member and a sense of group autonomy (Steinberg, 2003). The interconnectedness of mutual aid and a group-as-a-whole approach is highlighted in Steinberg's description of mutual aid practice as seeking "to establish a relationship not only between the worker and group members in the name of professional help but also among members in the name of creating exponential sources of help" (2003, pp. 36-37). The experience of empowering and 
supporting another group member, or engaging in the mutual aid process, increases one's sense of self-efficacy and empowerment (Knight \& Gitterman, 2014). The shared goals and experiences of group members promotes an "all-in-the-same-boat phenomenon" (Shulman, 2015) and a sense of universality (Yalom \& Leszcz, 2005).

\subsubsection{Group-As-A-Whole}

In order to access the power of mutual aid within the group, the group must be treated as a group-as-a-whole rather than just one individual at a time- - "the quality of the mutual aid process that occurs in a group is what differentiates group work from casework in a group." (Kurland \& Salmon, 2006, p. 130). At the same time, mutual aid and the group-as-a-whole phenomenon cannot take place until safety has been established (Kleinmuntz, 2011). When individuals come together to form a group, a unique phenomenon occurs and the group has the potential of solidifying into its own unique organism. The group-as-a-whole experience takes place through the process of group cohesion.

Group cohesion is emphasized by the International Association of Social Work with Groups Standards of Practice as an important beginning task of the social worker. The standards state that the group worker "aids the group members in establishing relationships with one another so as to promote group cohesion" (IASWG, 2015, p. 11). Research demonstrates that increasing group cohesion is related to increasing the influence of the group upon its members (Northen \& Kurland, 2001). Group cohesion's significance in group work has been compared to the importance of the therapeutic relationship in individual therapy (Yalom \& Lesczc, 2005). Group cohesion, the group-as-a-whole experience, group safety, and mutual aid emerge as an interdependent system in the group process.

Many social group work experts have criticized social workers for doing individual therapy or casework in a group setting instead of treating the group-as-a-whole (Bitel, 2014; Gitterman, 2004; Knight, 2017; Kurland \& Salmon, 2006). "The worker who sets in motion the process of mutual aid takes into account the entire group as an entity rather than just one individual at a time" (Kurland \& Salmon, 2006, p. 131). Unfortunately, the lack of group work education and training in social work education seems to be contributing to social workers' limited ability to work with the group-as-a-whole. Most group sessions today are unengaging, boring, and seem to be alternating segments of individual therapy with a group audience (Konopka, 1990). Jacob L. Moreno, the founder of sociometry and psychodrama, also criticized group workers for doing the same (1947).

Moreno's idea of group psychotherapy meant treating the group; other group therapists remained focused on the individual, and their methods could often be better described as treating individuals in a group setting. Individual psychotherapy, Moreno pointed out, is based on the psychodynamics of the individual. The treatment of a group is based on sociodynamics that involve the interrelationships and interactions of the members of the group, not just the collection of individuals and their personal dynamics. (Nolte, 2014, p. 122) 
The action-based tools that Moreno developed are inherently group-as-a-whole processes that treat the collective group as the identified client.

\subsubsection{Moreno's Sociometry as a Group-As-A-Whole Mutual Aid Process}

Jacob L. Moreno coined the terms "group therapy" and "group psychotherapy" in 1931 (Moreno, 1945; Moreno \& Whitin, 1932). However, he is an often forgotten pioneer of mutual aid and group-as-a-whole process. Very little has been written about the connection between Moreno's methods and social work with groups. Some view Moreno as a social worker due to his emphasis on working with society's oppressed and underserved communities with a focus on person-in-environment expressed by his sociometric system (Giacomucci, 2018a, 2018b, 2019; Giacomucci \& Stone, 2019; Skolnik, 2018; Stimmer, 2004; Wang \& Liu, 2020).

Moreno's mutual aid ideas began in 1913 through his experience of organizing a group of sex workers in Vienna-"we began to see then that one individual could become a therapeutic agent of the other and the potentialities of a group psychotherapy on the reality level crystallized in our mind" (1955, p. 22). Moreno attempted to dismantle the power dynamics between doctor and patient by pronouncing each group member as a therapeutic agent (Nolte, 2014). He argued that in group work, especially sociometry and psychodrama, participants experience healing through action and interaction between each other and the roles they play for each other - not from the psychodrama director or group facilitator (Moreno, 2000). He writes "the underlying principle is that each individual-not just the physician himself-may act as a therapeutic agent for every other individual, and each group as a therapeutic agent for another group" (1963, p. 149).

J. L. Moreno's existential theory of human nature posits that each individual possesses an "autonomous healing center"- the innate capacity to heal one's self (Moreno, 2012, 2019b). He believed that spontaneity is the key to the autonomous healing center and the curative agent in therapy (1953). In psychodrama's theory of change, spontaneity-creativity theory, spontaneity is defined as the ability to respond to new situations adequately and the capacity to respond in new ways to old, reoccurring (external or internal) circumstances (Moreno, 1964). In the contemporary social work with groups literature, Kleinmuntz argues that "mutual aid requires spontaneity" (2011, p. 222). In a group experience, the act of engaging in mutual aid and support for fellow group members is an adequate response to the group issues.

Zerka Moreno, the co-founder of psychodrama and wife of Jacob Moreno, writes in her memoir that "awakening the autonomous healing center, the power to heal oneself, is how I see the value of psychodrama and all forms of therapy" (2012, p. 504). Just as each individual has an autonomous healing center within and the capacity to heal one's self—so does each group (Giacomucci, 2019; Schreiber, 2018). The group process taps into the autonomous healing center once the group is properly 
warmed-up, connections are formed, safety is established, and the topic is representative of the group-as-a-whole. The group-as-a-whole is the protagonist accessing its autonomous healing center to heal itself. Mutual aid is the mechanism through which the group heals itself. J. L. Moreno not only believed in the healing potential of an individual and a group, but he also believed in society's potential to heal itself. This is evidenced by one of his most well-known quotes, "a truly therapeutic procedure must have no less objective than the whole of mankind" (Moreno, 1953, p. 1).

Moreno's sociometric and psychodramatic systems are intrinsically group-as-awhole, mutual aid processes (Giacomucci, 2019; Skolnik, 2018). Mutual aid "is inherently psycho and social in concept and in action" (Glassman \& Kates, 1990; Roberts \& Northen, 1976; Steinberg, 2004; as cited in Steinberg, 2010, p. 57). This quote from Steinberg describing mutual aid is also an accurate description of Moreno's experiential system of sociometry, psychodrama, and group psychotherapy. In his 1947 Open Letter to Group Psychotherapists, 14 years before Schwartz introduced mutual aid to social work, Moreno writes that "one patient can be a therapeutic agent to the other, let us invent devices by which they can help each other, in contrast to the older idea that all the therapeutic power rests with the physician" (p. 23).

\subsection{Strengths-Based Psychodrama}

The practice of psychodrama focused on mutual aid and strengths is still developing, as is its literature base-especially within the social work field (Giacomucci, 2019; Konopik \& Cheung, 2013). While psychodrama philosophy inherently emphasizes the strengths and positive healing power of individuals and groups, the intentional use of strengths within psychodrama practice is relatively new. It appears that there are four major forces that have led to the infusion of strengths-based approaches within the practice of psychodrama-Moreno's core philosophy of human nature, positive psychology, the Therapeutic Spiral Model, and Souldrama.

Saleebey's six core principles of the strengths-based approach (2012) are highly complementary and intrinsic to sociometry and psychodrama practice. The Morenean approach acknowledges the strengths of each individual, group, and community while also assuming that every environment is full of resources and mutual aid. Psychodrama employs surplus reality which transcends the limits of the environment and accesses resources from beyond reality. Psychodramatists empower protagonists and groups through collaboration, mutual aid, and co-creation toward the goals and aspirations of the group. The psychodramatic approach inspires clients, within the compassionate relational framework of the group, to revisit past trauma and injury with opportunities for correction, repair, and post-traumatic growth in action.

The three categories of post-traumatic growth-enhanced sense of self, relationships, and life philosophy (Calhoun \& Tedeschi, 2012)—strongly related to the body of work of Jacob Moreno. In his Sociometry and the Cultural Order (1943), Moreno writes that he developed three core ideas-his spiritual/existential philosophy, psychodrama, and sociometry. "The first idea initiates a cannon of the 
universe, the second a cannon of the individual, the third a cannon of human society" (Moreno, 1943, p. 299). These three cannons parallel the three categories of post-traumatic growth. Psychodrama offers an avenue for improved sense of self; sociometry provides an increased sense of relationships; and Moreno's spiritual philosophy offers an optimistic framework for understanding life, the universe, and the boundlessness of possibilities.

\subsubsection{Morenean Philosophy as Strengths-Based Humanistic Approach}

The existential and spiritual philosophy from which psychodrama emerged is fundamentally a strengths-based humanistic approach. Moreno exclaims that "psychodrama is based on the premise that every man is a genius" (2019b, p. 12). Moreno's framework challenges the medical model and its pathologizing nature while conceptualizing human beings as genius, godlike, and active agents within the world (Moreno, 2019b). In his autobiography, he explicitly declares all human beings as potential geniuses. He puts forth three hypotheses in the introduction to his Autobiography of a Genius stating: (1) spontaneity-creativity is the propelling force of human progress; (2) love and mutual sharing are of the most important principles of group life, and we should have faith in the intentions of others; (3) a super-dynamic society can be built upon these principles in which all humans are empowered as co-creators and co-responsible. For Moreno, Fox writes, "what characterizes human nature is an unlimited capacity for spontaneous and creative action. Moreno believed this and as such his outlook is an optimistic one" (1987, p. 39).

Zerka Moreno states in her memoir that her husband believed that instead of focusing on man's failings, we should emphasize man's genius (2012). Jonathan, Jacob Moreno's son, echoes this stance and stating:

His confidence in the healing power of the group was founded upon his faith that, in principle, altruistic human love is an infinite resource. In those days the prevailing psychoanalytic temper in America reduced human nature to its basest components, an attitude Moreno found one-dimensional and destructive. (Moreno, 2019a, p. 108)

Taking this into consideration, Moreno seems to have been one of the first to promote a humanistic strengths-based approach in psychiatry and psychotherapy. Bustos (1994), credits Moreno to have "offered a new way of looking at human suffering which was more sympathetic and based on health rather than on pathology" (p. 50). It is only fitting then that his tombstone reads "the man who brought laughter into psychiatry" (Orkibi, 2019).

Moreno's vision of the goodness and potential within human nature is quite similar to Maslow's writings on self-actualization and "Being psychology" or "positive psychology" (Maslow, 1962, 1964). There are also many comparisons that could be drawn between Moreno's approach with the humanistic theories and person-centered approach proposed by Carl Rogers (Rogers, 1951, 1966; Moreno, 2014; von Ameln \& 
Becker-Ebel, 2020). Perhaps the biggest difference is that client-centered approaches were primarily employed with individual psychotherapy clients. Considering the group as the client, Moreno's group approaches are inherently group-centered or client-centered. Moreno's philosophy of human nature and his approach to clients appear largely congruent with the humanistic psychologists.

Moreno's group therapy movement and the humanistic psychology movement had much in common philosophically. Both were rooted in existential philosophy. They both emerged in opposition to psychoanalysis and behaviorism promoting a more positive view of human nature. Coincidentally, leaders of both group therapy and the humanistic psychology fields have declared their own respective movements as the third wave or third revolution in psychology (Moreno, 2014).

\subsubsection{Positive Psychology and Positive Psychodrama}

The relationship between strengths-based social work and positive psychology seems to reflect the relationship between psychodrama and positive psychology in that psychodrama preceded positive psychology by nearly a century but failed to professionalize in and be accepted in the larger culture in the way positive psychology did. Positive psychology emphasizes the importance of a psychology of health and the exploration of character strengths, well-being, and happiness. Moreno's challenge to psychoanalysis and the medical model reflected a similar shift in perspective. The rise of positive psychology in the late 1990s and early 2000s brought with it new language and increased momentum for consciously integrating positive psychology principles into the field of psychodrama. Tomasulo (2018) notes that there are overlapping elements within the pre-history of positive psychology and psychodrama. The Human Potential Movement of the 1960s embraced psychodrama, along with other approaches, and concretized a foundation for contemporary positive psychology (Atkinson \& Kirsner, 2019; Moreno, 2014). Tomasulo highlights that Csikszentmihalyi, co-founder of positive psychology, was influenced by Moreno's philosophy of spontaneity. Csikszentmihalyi even had help from prominent psychodramatist, David Kipper, in preparing his groundbreaking publication Flow: The Psychology of Optimal Experience (1976/1990) which reflects many similarities to Moreno's concept of spontaneity. Tomasulo describes psychodrama, positive psychology, and positive psychotherapy as "three strands of a braided vine... woven together since their beginnings" (2018, p. 49).

Goldberg (2009) offers one of the first articles integrating positive psychology and psychodrama into a new model she described as Positive Psychodrama. She writes that Positive Psychodrama's goal "is to access strengths and virtues, the genius within, as well as to conceptualize how to use these strengths in life" (Goldberg, 2009, p. 367). Atkinson and Kirsner (2019) outline their use of the Values In Action Character Strengths integrated with experiential sociometry and psychodrama interventions-effectively synthesizing the content of positive psychology and strengthsbased approach with the process of sociometry and psychodrama. Tomasulo has 
also written various pieces on the topic $(2011,2014,2018,2019)$-maybe best known for the Virtual Gratitude Visit which uses psychodrama role-playing techniques to enhance a popular positive psychology intervention involving writing and delivering a letter of gratitude (Tomasulo, 2019). Tomasulo also notes that many psychodramatists have integrated the assessment of character strengths into their work which he originally did through a modified social atom assessment called a strengths atom (2018). Orkibi (2019) offers a structured framework for integrating positive psychology and psychodrama into what he also calls Positive Psychodrama. Orkibi's (2019) article presents the intersections between positive psychology and psychodrama through the five following psychodrama concepts: (1) spontaneity, creativity, and adaptation; (2) sociatry and positive relationships; (3) co-creation and mutual responsibility; (4) roles repertoire and character strengths; and (5) act hunger, flow, and engagement. Orkibi writes that Positive Psychodrama "therefore highlights the inherently positive theoretical underpinning of Moreno's theory and philosophy" (2019, p. 6). Atkinson \& Kirsner (2019) echo these theoretical similarities and declare that "positive psychology and action methods fit together like hand and glove"-sharing a humanistic, existential view of mankind while emphasizing connection, authenticity, well-being, creativity, spontaneity, flow, choice, the here-and-now, and the use of future projection of possible selves (p. 316).

\subsubsection{Therapeutic Spiral Model}

The Therapeutic Spiral Model (TSM) was developed in the early 1990s as a response to classical psychodrama's potential for retraumatizing participants with trauma histories. TSM is a clinically modified approach with emphasis on strengths, safety, and containment (Giacomucci \& Marquit, 2020). As noted in Sect. 7.8, TSM offers multiple strengths-based contributions to the field including the Circle of Strengths warm-up exercise as a clinical map prescribing roles of strength before addressing trauma psychodramatically (Hudgins \& Toscani, 2013). TSM proposes three categories of strengths required for healthy personality functioning after traumaintrapsychic strengths, interpersonal strengths, and transpersonal strengths (Hudgins, 2019). TSM's clinical map, the Trauma Survivors Intrapsychic Role Atom (TSIRA) outlines nine strengths-based roles in the first phase of the clinical map (Giacomucci, 2018c). TSM psychodrama in practice often includes what are called prescriptive role psychodramas which are psychodrama focused entirely on strengths-based roles without any antagonist, trauma-based, or negative roles in the scene (Hudgins, 2002).

The second phase of the TSM clinical map orients itself upon trauma content and trauma-based roles, while the third phase proposes transformative role templates (Giacomucci, 2017). The third phase of transformative roles have been described as roles of post-traumatic growth and compared to the categories of post-traumatic growth (Giacomucci, 2018c). TSM's clinical map guides facilitators to start with roles of strength and to end with roles of post-traumatic growth which provides increased safety and a cushioning from the trauma. The use of strengths as roles in TSM 
psychodrama enactments is foundational and utilized in every TSM psychodrama. This implementation of strengths as psychodrama roles seems to have become integrated throughout the larger psychodrama community in part because of TSM's contribution.

\subsubsection{Souldrama}

Souldrama is a modified psychodrama approach, developed by Miller (2000, 2004) with a focus on spirituality and the 12-steps from Alcoholics Anonymous. Souldrama emphasizes Moreno's concept of the divinity of each human being (Ozcan, 2019) and is primarily used with populations interested in religion, spirituality, and/or struggling with addiction or codependency. Miller (2008) writes:

A goal of the Souldrama experience is to help individuals identify their authentic meaning and purpose in life. This is a formidable goal, as our purpose reflects what we naturally do best in life and helps us best use our gifts, talents, and skills. (p. 139)

Interestingly, Miller (2008) even references Csikszentmihalyi's concept of flow as it relates to Souldrama's focus on spirituality and well-being. Miller describes seven stages or doors to spiritual transformation including faith, truth, compassion, love, humility, gratitude, and inspiration (2008). These seven stages encompass the development of rational, emotional, and spiritual intelligence. Miller describes Souldrama as a "transpersonal psycho-spiritual action technique" that "combines mind, body, and spirit to create therapeutic energy within a group process" (2019, p. 289). The entire framework of Souldrama appears to be one based in strengths, virtues, and spirituality. Like TSM, Souldrama's strengths-based approach has taken root around the world with regular training groups and now trained practitioners practicing in multiple countries and continents.

\subsection{Conclusion}

Classical psychodrama, along with the aforementioned modified psychodrama models, are experiential group processes that both explicitly and implicitly employ a strengths-based approach. Implicit within the philosophy and theory of sociometry and psychodrama is an emphasis on the strengths, goodness, and even the godlikeness of each individual, group, and society. Psychodrama explicitly acknowledges and interfaces with strengths through the psychodramatic process. The core concepts of strengths-based psychodrama and of post-traumatic growth are parallel to Moreno's philosophy and methods. Mutual aid, the foundation of social group work, is also central in sociometric and psychodramatic approaches (Giacomucci, 2020). As the practice of psychodrama evolved with new psychodrama models (positive psychodrama, the Therapeutic Spiral Model, Souldrama, and others), it continues to 
move more toward a strengths-based orientation. While mutual aid and a strengthsbased approach are core to the social work profession and especially social work with groups, Moreno's work seems to have outlined a strengths-based mutual aid model decades prior to their emergence in the social work field.

Acknowledgements Content on pages 166-169 (Sect. 9.3) is republished from Giacomucci, S. (2020). Experiential sociometry in group work: Mutual aid for the group-as-a-whole. Social Work with Groups, Advanced Online Publication: https://www.tandfonline.com/doi/abs/10.1080/ 01609513.2020.1747726. Reprinted by permission of the publisher (Taylor and Francis Ltd., https:// www.tandfonline.com).

\section{References}

Alisic, E., Van der Schoot, T. A., van Ginkel, J. R., \& Kleber, R. J. (2008). Looking beyond posttraumatic stress disorder in children: Posttraumatic stress reactions, posttraumatic growth, and quality of life in a general population sample. Journal of Clinical Psychiatry, 69(9), 1455-1461.

Alschuler, M., Silver, T., \& McArdle, L. (2015). Strengths-based group supervision with social work students. Groupwork, 25(1), 34-57.

Arnold, D., Calhoun, L. G., Tedeschi, R., \& Cann, A. (2005). Vicarious posttraumatic growth in psychotherapy. Journal of Humanistic Psychology, 45(2), 239-263.

Atkinson, P., \& Kirsner, N. (2019). Positive psychology and psychodrama. In A. Blatner (Ed.), Action explorations: Using psychodramatic methods in non-therapeutic settings (pp. 315-332). Seattle, WA: Parallax Publications.

Baruth, K., \& Carroll, J. (2002). A formal assessment inventory of resilience: The Baruth protective factors inventory. Journal of Individual Psychology, 58, 235-244.

Bauwens, J., \& Tosone, C. (2010). Professional posttraumatic growth after a shared traumatic experience: Manhattan clinicians' perspectives on post-9/11 practice. Journal of Loss and Trauma, 15(6), 498-517.

Bitel, M. (2014). Flipping the equation: The need for context-focused group work education. Social Work with Groups, 37, 48-60.

Bluvstein, I., Moravchick, L., Sheps, D., Schreiber, S., \& Bloch, M. (2013). Posttraumatic growth, posttraumatic stress symptoms and mental health among coronary heart disease survivors. Journal of Clinical Psychology in Medical Settings, 20(2), 164-172.

Breslau, N., Davis, G. C., Andreski, P., \& Peterson, E. (1991). Traumatic events and posttraumatic stress disorder in an urban population of young adults. Archives of General Psychiatry, 48(3), 216-222.

Bustos, D. M. (1994). Locus, matrix, status nascendi and the concept of clusters. In P. Holmes, M. Karp, \& M. Watson (Eds.), Psychodrama since Moreno: Innovations in theory and practice (pp. 45-55). New York: Routledge.

Calhoun, L. G., \& Tedeschi, R. G. (2012). Posttraumatic growth in clinical practice. New York: Routledge.

Calhoun, L. G., \& Tedeschi, R. G. (Eds.). (2014). Handbook of posttraumatic growth: Research and practice. Routledge.

Canda, E. R. (2012). Chronic illness and spiritual transformation. In D. Saleebey (Ed.), The strengths perspective in social work practice (6th ed., pp. 79-96). Boston: Pearson Education.

Chesner, A. (2020). Psychodrama and healing the traumatic wound. In A. Chesner \& S. Lykou (Eds.), Trauma in the creative and embodied therapies: When words are not enough (pp. 69-80). London: Routledge. 
Cohen, B. Z. (1999). Intervention and supervision in strengths-based social work practice. Families in Society, 80(5), 460-466.

Cohen, K., \& Collens, P. (2013). The impact of trauma work on trauma workers: A metasynthesis on vicarious trauma and vicarious posttraumatic growth. Psychological Trauma: Theory, Research, Practice, and Policy, 5(6), 570-580.

Cossa, M. (2020). Building resilience in youth with Therapeutic Spiral Model ${ }^{\mathrm{TM}}(\mathrm{TSM})$ psychodrama. Zeitschrift Für Psychodrama Und Soziometrie, 19(1), 51-62.

Courtois, C. A., \& Ford, J. D. (2016). Treatment of complex trauma: A sequenced, relationship-based approach. New York, NY: The Guildford Press.

Cosden, M., Sanford, A., Koch, L. M., \& Lepore, C. E. (2016). Vicarious trauma and vicarious posttraumatic growth among substance abuse treatment providers. Substance Abuse, 37(4), 619624.

Csikszentmihalyi, M. (1976/1990). Flow: The psychology of optimal experience: Steps toward enhancing the quality of life. New York, NY: Harper Collins.

Dewey, J. (1916). Democracy and education: An introduction to the philosophy of education. New York: The Free Press.

Epstein, M. H., \& Sharma, J. M. (1998). Behavioral and emotional rating scale: A strength-based approach to assessment. Austin, TX: PRO-ED.

Fox, J. (Ed.). (1987). The essential Moreno: Writings on psychodrama, group method, and spontaneity by J. L. Moreno, M.D. New York: Springer.

Fraser, M. W., Kirby, L. D., \& Smokowski, P. R. (2004). Risk and resilience in childhood. Risk and Resilience in Childhood: An Ecological Perspective, 2, 13-66.

Frazier, P., Conlon, A., \& Glaser, T. (2001). Positive and negative life changes following sexual assault. Journal of Consulting and Clinical Psychology, 69, 1048-1055.

Frazier, P., Tennen, H., Gavian, M., Park, C., Tomich, P., \& Tashiro, T. (2009). Does self-reported posttraumatic growth reflect genuine positive change? Psychological Science, 20, 912-919.

Froh, J. J. (2004). The history of positive psychology: Truth be told. NYS Psychologist, 16(3), 18-20.

Giacomucci, S. (2017). The sociodrama of life or death: Young adults and addiction treatment. Journal of Psychodrama, Sociometry, and Group Psychotherapy, 65(1), 137-143. https://doi. org/10.12926/0731-1273-65.1.137.

Giacomucci, S. (2018). Social work and sociometry: An integration of theory and clinical practice. The Pennsylvania Social Worker, 39(1), 14-16.

Giacomucci, S. (2018b). Social work and sociometry: Integrating history, theory, and practice. In Clinical Voice (pp. 15-16). Richboro, PA: Pennsylvania Society for Clinical Social Work.

Giacomucci, S. (2018). The trauma survivor's inner role atom: A clinical map for post-traumatic growth. Journal of Psychodrama, Sociometry, and Group Psychotherapy., 66(1), 115-129.

Giacomucci, S. (2019). Social group work in action: A sociometry, psychodrama, and experiential trauma therapy curriculum. Doctorate in Social Work (DSW) Dissertations, pp. 124. https://rep ository.upenn.edu/cgi/viewcontent.cgi?article=1128\&context=edissertations_sp2.

Giacomucci, S. (2020). Experiential sociometry in group work: Mutual aid for the group-as-a-whole. Social Work with Groups. https://doi.org/10.1080/01609513.2020.1747726.

Giacomucci, S., \& Marquit, J. (2020). The effectiveness of trauma-focused psychodrama in the treatment of PTSD in inpatient substance abuse treatment. Frontiers in Psychology, 11, 896. https://doi.org/10.3389/2Ffpsyg.2020.00896.

Giacomucci, S., \& Stone, A. M. (2019). Being in two places at once: Renegotiating traumatic experience through the surplus reality of psychodrama. Social Work with Groups, 42(3), 184-196. https://doi.org/10.1080/01609513.2018.1533913.

Gilligan, R. (2004). Promoting resilience in child and family social work: Issues for social work practice, education, and policy. Social Work Education, 23, 93-104.

Gitterman, A. (2004). Interactive andragogy: Principles, methods, and skills. Journal of Teaching in Social Work, 24(3/4), 95-112. 
Gitterman, A., \& Knight, C. (2016). Promoting resilience through social work practice with groups: Implications for the practice and field curricula. Journal of Social Work Education, 52(4), 448461.

Gitterman, A., \& Shulman, L. (2005). Mutual aid groups, vulnerable and resilient populations, and the life cycle (3rd ed.). New York, NY: Columbia University Press.

Glassman, U., \& Kates, L. (1990). Group work: A humanistic approach. Newbury Park, CA: Sage.

Goldberg, M. C. (2009). Positive psychodrama and the early works of JL Moreno. Group, 359-372.

Herman, J. L. (1997). Trauma and recovery: The aftermath of violence-from domestic abuse to political terror. New York: Basic Books.

Hudgins, M. K. (2002). Experiential treatment for PTSD: The therapeutic spiral model. New York: Springer Publishing Company.

Hudgins, K. (2019). Psychodrama revisited: Through the lens of the internal role map of the therapeutic spiral model to promote post-traumatic growth. Zeitschrift Für Psychodrama Und Soziometrie, 18(1), 59-74.

Hudgins, M. K., \& Toscani, F. (2013). Healing world trauma with the therapeutic spiral model: stories from the frontlines. London: Jessica Kingsley Publishers.

Hyatt-Burkhart, D. (2014). The experience of vicarious posttraumatic growth in mental health workers. Journal of Loss and Trauma, 19(5), 452-461.

International Association of Social Work with Groups. (2015). Standards for Social Work Practice with Groups (2nd ed.). Retrieved from: https://www.iaswg.org/assets/docs/Resources/2015_I ASWG_STANDARDS_FOR_SOCIAL_WORK_PRACTICE_WITH_GROUPS.pdf.

Jia, X., Ying, L., Zhou, X., Wu, X., \& Lin, C. (2015). The effects of extraversion, social support on the posttraumatic stress disorder and posttraumatic growth of adolescent survivors of the Wenchuan earthquake. PLoS One, 10(3).

Kessler, R. C., Sonnega, A., Bromet, E., Hughes, M., \& Nelson, C. B. (1995). Posttraumatic stress disorder in the national comorbidity survey. Archives of General Psychiatry, 52(12), 1048-1060.

Kim, J. S., \& Bolton, K. W. (2013). Strengths perspective. In Encyclopedia of Social Work. Retrieved February 29, 2020, from https://oxfordre.com/socialwork/view/https://doi.org/10.1093/acrefore/ 9780199975839.001.0001/acrefore-9780199975839-e-382.

Kleinmuntz, J. (2011). On becoming a group worker. Social Work with Groups, 34(3-4), 219-232.

Knight, C. (2006). Groups for individuals with traumatic histories: Practice considerations for social workers. Social Work, 51(1), 20-30.

Knight, C. (2017). Social work students' experiences with group work in the field practicum. Journal of Teaching in Social Work, 37(2), 138-155.

Knight, C., \& Gitterman, A. (2014). Group work with bereaved individuals: The power of mutual aid. Social Work, 59(1), 5-12.

Konopik, D. A., \& Cheung, M. (2013). Psychodrama as a social work modality. Journal of Social Work, 58(1), 9-20.

Konopka, G. (1990). Past/present issues in group work with the emotionally disabled: Part II, thirty-five years of group work in psychiatric settings. Social Work with Groups, 13(1).

Kretzmann, J. P., \& McKnight, J. (1993). Building communities from the inside out (pp. 2-10). Evanston, IL: Center for Urban Affairs and Policy Research, Neighborhood Innovations Network.

Kropotkin, P. A. (1922). Mutual aid: A factor of evolution. New York, NY: Knopf.

Kurland, R., \& Salmon, R. (2006). Group work vs. casework in a group: Principles and implications for teaching and practice. Social Work with Groups, 28(3-4), 121-132.

Maslow, A. H. (1954). Motivation and personality. New York: Harper \& Row, Publishers.

Maslow, A. H. (1962). Toward a psychology of being. New York: Wiley.

Maslow, A. H. (1964). Religions, values, and peak-experiences. Columbus: Ohio State University Press.

Manning, S. F., de Terte, I., \& Stephens, C. (2015). Vicarious posttraumatic growth: A systematic literature review. International Journal of Wellbeing, 5(2).

McMillen, C., Smith, E. M., \& Fisher, R. H. (1997). Perceived benefit and mental health after three types of disaster. Journal of Consulting and Clinical Psychology, 65, 733-739. 
Mead, G. H. (1934). Mind, self and society (Vol. 111). Chicago, IL: University of Chicago Press.

Mendelsohn, M., Zachary, R., \& Harney, P. (2007). Group therapy as an ecological bridge to new community for trauma survivors. Journal of Aggression, Maltreatment and Trauma, 14, 227-243.

Miller, C. (2000). The technique of Souldrama and its applications. Journal of Group Psychotherapy, Psychodrama and Sociometry, 52(4), 173-186.

Miller, C. (2004). Souldrama: A journey into the heart of God. NJ: Self-published.

Miller, C. (2008). Souldrama®: Spirituality in action. Journal of Creativity in Mental Health, 3(2), 139-156.

Miller, C. (2019). Souldrama. In A. Blatner (Ed.), Action explorations: Using psychodramatic methods in non-therapeutic settings (pp. 287-298). Seattle, WA: Parallax Publications.

Moreno, J. L. (1943). Sociometry and the cultural order. Sociometry, 6(3), 299-344.

Moreno, J. L. (1945). Group psychotherapy: A symposium. Beacon, NY: Beacon House Press.

Moreno, J. L. (1947). Open letter to group psychotherapists. Psychodrama Monograms, No. 23. Beacon, NY: Beacon House.

Moreno, J. L. (1953). Who shall survive? Foundations of sociometry, group psychotherapy and sociodrama (2nd ed.). Beacon, NY: Beacon House.

Moreno, J. L. (1955). Preludes to my autobiography. Beacon, NY: Beacon House.

Moreno, J. L. (1963). Reflections on my method of group psychotherapy and psychodrama. Ciba Symposium, 11(4), 148-157.

Moreno, J. L. (1964). Psychodrama, first volume (3rd ed.). Beacon, NY: Beacon House Press.

Moreno, J. D. (2014). Impromptu man: JL Moreno and the origins of psychodrama, encounter culture, and the social network. Bellevue Literary Press.

Moreno, J. D. (2019a). Introduction. In J. L. Moreno (Ed.), The autobiography of a genius (pp. 107115). United Kingdom: North West Psychodrama Association.

Moreno, J. L. (2019b). The autobiography of a genius. In: E. Schreiber, S. Kelley, \& S. Giacomucci (Eds.). United Kingdom: North West Psychodrama Association.

Moreno, J. L., \& Whitin, E. S. (1932). Application of the group method to classification. New York: National Committee on Prisons and Prison Labor.

Moreno, Z.T. (2000). Interview with Leif Dag Blomkvist regarding Surplus Reality. In Z. T. Moreno, L. D. Blomkvist, \& T. Rutzel (Eds.), Psychodrama, surplus reality and the art of healing (Chap. 4, pp. 17-23). London, UK: Routledge.

Moreno, Z. T. (2012). To dream again: A memoir. New York: Mental Health Resources.

Najavits, L. (2002). Seeking safety: A treatment manual for PTSD and substance abuse. Guilford Publications.

Nolte, J. (2014). The philosophy, theory, and methods of J. L. Moreno: The man who tried to become god. New York, NY: Routledge.

Norman, E. (Ed.). (2000). Resiliency enhancement: Putting the strength perspective into social work practice. New York: Columbia University Press.

Northen, H., \& Kurland, R. (2001). Social work with groups. New York: Columbia University Press.

Orkibi, H. (2019). Positive psychodrama: A framework for practice and research. Arts in Psychotherapy, 66, 1-8. https://doi.org/10.1016/j.aip.2019.101603.

Özcan, G. (2019). Psychodrama and spirituality: A practice-friendly review. Spiritual Psychology and Counseling, 4(1), 39-55.

Parikh, D., De Ieso, P., Garvey, G., Thachil, T., Ramamoorthi, R., Penniment, M., \& Jayaraj, R. (2015). Post-traumatic stress disorder and post-traumatic growth in breast cancer patients-a systematic review. Asian Pacific Journal of Cancer Prevention, 16(2), 641-646.

Park, C. L., Cohen, L. H., \& Murch, R. L. (1996). Assessment and prediction of stress-related growth. Journal of Personality, 64, 71-105.

Probst, B. (2010). Implicit and explicit use of the strengths perspective in social work education. Journal of Teaching in Social Work, 30(4), 468-484.

Rapp, C. A. (1998). The strengths model: Case management with people suffering from severe and persistent mental illness. New York: Oxford University Press. 
Rapp, C. A., \& Chamberlain, R. (1985). Case management services for the chronically mentally ill. Social Work, 30(5), 417-422.

Rapp, C. A., Saleebey, D., \& Sullivan, W. P. (2006). The future of strengths-based social work. Advances in Social Work: Special Issue on the Futures of Social Work, 6(1), 79-90.

Rashid, T. (2015). Positive psychotherapy: A strength-based approach. The Journal of Positive Psychology, 10(1), 25-40.

Roberts, R., \& Northen, H. (1976). Theories of social work with groups. New York: Columbia University Press.

Rogers, C. (1951). Client-centered therapy: Its current practice, implications and theory. London: Constable.

Rogers, C. R. (1966). Client-centered therapy. Washington, DC: American Psychological Association.

Saleebey, D. (1996). The strengths perspective in social work practice: Extensions and cautions. Social Work, 41(3), 296-305.

Saleebey, D. (2012). The strengths perspective in social work practice (6th ed.). Boston: Pearson Education.

Santiago, P. N., Ursano, R. J., Gray, C. L., Pynoos, R. S., Spiegel, D., Lewis-Fernandez, R., ... \& Fullerton, C. S. (2013). A systematic review of PTSD prevalence and trajectories in DSM-5 defined trauma exposed populations: intentional and non-intentional traumatic events. PloS one, $8(4)$.

Schreiber, E. (2018). Sociatry Part 2: Moreno's Mysticism. In Psychodrama network news (Winter 2018, pp. 24-25). American Society of Group Psychotherapy and Psychodrama.

Schwartz, W. (1961). The social worker in the group. In New perspectives on services to groups: Theory, organization, and practice (pp. 7-34).

Seligman, M.E. P. (1998). Building human strengths: psychology's forgotten mission. APA Monitor, January 2.

Shapiro, F. (2018). Eye-movement desensitization and reprocessing (EMDR) therapy (3rd ed.). New York: Guilford Press.

Shulman, L. (2015). The skills of helping individuals, families, groups, and communities (8th ed.). Boston, MA: Cengage Learning.

Skolnik-Basulto, S. (2016). Coming together: A study of factors that influence social workers' connection to group work practice (Order No. 10758221). Available from ProQuest Dissertations \& Theses Global. (1988269052). Retrieved from https://proxy.library.upenn.edu/login? url=https://proxy.library.upenn.edu:2072/docview/1988269052?accountid=14707.

Skolnik, S. (2018). A synergistic union: Group work meets psychodrama. Social Work with Groups, $41(1-2), 60-73$.

Smith, E. J. (2006). The strength-based counseling model. The Counseling Psychologist, 34(1), $13-79$.

Ssenyonga, J., Owens, V., \& Olema, D. K. (2013). Posttraumatic growth, resilience, and posttraumatic stress disorder (PTSD) among refugees. Procedia-Social and Behavioral Sciences, 82, 144-148.

Steinberg, D. M. (2003). The magic of mutual aid. Social Work with Groups, 25(1-2), 31-38.

Steinberg, D. M. (2004). The mutual-aid approach to working with groups (2nd ed.). Binghamton, NY: Haworth Press.

Steinberg, D. M. (2010). Mutual aid: A contribution to best-practice social work. Social Work with Groups, 33(1), 53-68.

Stimmer, F. (2004). Psychodrama - Soziale Arbeit - Netzwerke. Zeitschrift Für Psychodrama Und Soziometrie, 3(1), 17-27.

Tedeschi, R. G., \& Calhoun, L. G. (1996). The Posttraumatic growth inventory: Measuring the positive legacy of trauma. Journal of Traumatic Stress, 9(3), 455-471.

Tomasulo, D. (2011). The virtual gratitude visit (VGV): Psychodrama in action. Retrieved from PsychologyToday.com. 
Tomasulo, D. J. (2014). Positive group psychotherapy modified for adults with intellectual disabilities. Journal of Intellectual Disabilities, 18(4), 337-350.

Tomasulo, D. (2018). Beautiful thinking in action: Positive psychology, psychodrama, and positive psychotherapy. The Journal of Psychodrama, Sociometry, and Group Psychotherapy, 66(1), 4967.

Tomasulo D. J. (2019). The virtual gratitude visit (VGV): Using psychodrama and role-playing as a positive intervention. In L. Van Zyl \& S. Rothmann (Eds.), Positive psychological intervention design and protocols for multi-cultural contexts. Cham: Springer.

van Breda, A. D. (2018). A critical review of resilience theory and its relevance for social work. Social Work, 54(1), 1-18. https://doi.org/10.15270/54-1-611.

von Ameln, F., \& Becker-Ebel, J. (2020). Fundamentals of psychodrama. Singapore: Springer Nature.

Wade, J. C., \& Jones, J. E. (2014). Strength-based clinical supervision: A positive psychology approach to clinical training. Springer Publishing Company.

Walsh, F. (2006). Strengthening family resilience (2nd ed.). New York: The Guilford Press.

Wang, X. H., \& Liu, A. Q. (2020). Psychodrama: A professional method for social work. Social Work and Management, 20(2), 65-70.

Weick, A., Rapp, C., Sullivan, W. P., \& Kisthardt, W. (1989). A strengths perspective for social work practice. Social Work, 34(4), 350-354.

Witkin, S. (2017). Transforming social work: Social constructionist reflections on contemporary and enduring issues. London: Palgrave.

Wolin, S., \& Wolin, S. J. (1993). The resilient self: How survivors of troubled families rise above adversity. New York: Villard.

Wu, X., Kaminga, A. C., Dai, W., Deng, J., Wang, Z., Pan, X., \& Liu, A. (2019). The prevalence of moderate-to-high posttraumatic growth: A systematic review and meta-analysis. Journal of Affective Disorders, 243, 408-415.

Yalom, I., \& Leszcz, M. (2005). The theory and practice of group psychotherapy. New York: Basic Books.

Open Access This chapter is licensed under the terms of the Creative Commons Attribution 4.0 International License (http://creativecommons.org/licenses/by/4.0/), which permits use, sharing, adaptation, distribution and reproduction in any medium or format, as long as you give appropriate credit to the original author(s) and the source, provide a link to the Creative Commons license and indicate if changes were made.

The images or other third party material in this chapter are included in the chapter's Creative Commons license, unless indicated otherwise in a credit line to the material. If material is not included in the chapter's Creative Commons license and your intended use is not permitted by statutory regulation or exceeds the permitted use, you will need to obtain permission directly from the copyright holder.

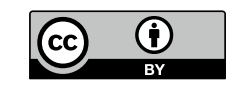

